\title{
Impact of Nile River outflow on Water Quality and Bacterial Diversity of Marine Water of the Egyptian Coast of the Mediterranean Sea
}

\author{
Nouran A. E. Zoromba ${ }^{1 *}$, Magdy M. Bahgat ${ }^{2}$, Mohamed I. Abou-Dobara ${ }^{3}$ and Mahmoud M. Zaky ${ }^{1}$ \\ ${ }^{1}$ Faculty of Science, Port Said University, Botany Department, Port Said, Egypt. \\ ${ }^{2}$ College of Pharmacy, Jazan University, Saudi Arabia. \\ ${ }^{3}$ Faculty of Science, Damietta University, Botany and Microbiology Department, Damietta, Egypt.
}

Received: 25 November 2016 /Accepted: 2 January 2017

*Corresponding author: nouran.zoromba@ hotmail.com

\begin{abstract}
In comparison between the eastern and western coasts of the Mediterranean Sea of Egypt, water samples were collected seasonally from Port Fouad City and Damietta branch of the Nile River during four successive seasons. Water samples were tested for some physical and chemical parameters including: water turbidity, TSS and chlorophyll-a as well as the determination of water salinity, $\mathrm{pH}$, concentrations of some nutrient salts and trace metals such as: $\mathrm{Cl}^{-}, \mathrm{Na}^{+}, \mathrm{K}^{+}, \mathrm{Mg}^{+2}$, $\mathrm{Ca}^{+2}, \mathrm{PO}_{4}^{-3}, \mathrm{NO}_{3}{ }^{-}, \mathrm{SO}_{4}^{-2}, \mathrm{Fe}^{+3}, \mathrm{Cu}^{+2}, \mathrm{Zn}^{+2}$ and $\mathrm{Mn}^{+2}$. Total bacterial counts of collected water samples were determined as well as biochemical identification of 17 bacterial genera. Results showed that the western coast of the Egyptian Mediterranean Sea recorded higher salinity values and higher concentrations of $\mathrm{Cl}^{-}$ions than those recorded in the eastern coast represented in Port Fouad City. Water turbidity values showed strong positive significant correlations between Alexandria and Port Fouad as well as Port Fouad and the Nile River while non-significant correlations occurred between water turbidity of Alexandria site and the Nile River site.
\end{abstract}

Keywords: Nile River, Mediterranean Sea, bacteria, nutrient, trace metals.

\section{Introduction}

Water quality is neither a static condition of a system, nor can it be defined by the measurement of only one parameter. Rather, it is variable in both time and space and requires routine monitoring to detect spatial patterns and changes over time [1]. There is a range of chemical, physical, and biological components that affect water quality and hundreds of variables could be examined and measured [1].
The Mediterranean Sea constitutes the largest area $\left(2969000 \mathrm{~km}^{2}\right)$ and deepest average of depth $(1460 \mathrm{~m})$ enclosed Sea on Earth [2]. In the West, it is connected to the Atlantic Ocean via the Strait of Gibraltar, in the Northeast through the Dardanelles to the Black Sea and the Sea of Marmara, while the Suez Canal in the Southeast links the Mediterranean Sea to the Red Sea and the Indian Ocean [2].

The entire Mediterranean Sea is oligotrophic [3]. One major characteristic of the Mediterranean Sea is a strong West-East gradient regarding 
surface nutrient concentrations with a sharp change at the transition between the two basins so that the eastern basin is ultra-oligotrophic whereas the western basin is oligotrophic [4]. The modified Atlantic water (MAW) outflows along the African coast off the Nile River, then around Cyprus [5]. Therefore the Nile River water spread over the sea surface and are deflected eastward along the coast toward the Levantine Sea [6].

The Egyptian Mediterranean coast lies at the South East sector of the Levantine sub-basin, from longitudes $25^{\circ} 30^{\prime} \mathrm{E}$ to $34^{\circ} \mathrm{E}$ and extends northwards to latitude $33^{\circ} \mathrm{N}$ [6]. The salinity of the Mediterranean Sea is uniformly high throughout the basin, surface water averages about $38 \%$ except the extreme western parts, and the salinity can approach $40 \%$ in the Eastern Mediterranean during the summer season; the salinity of seawater is made up of all the dissolved salts. Six major ions make up $99 \%$ of the total dissolved salts in seawater; they are $\mathrm{Na}^{+}$, $\mathrm{Cl}^{-}$, and $\mathrm{SO}^{-2}, \mathrm{Mg}^{+2}, \mathrm{Ca}^{+2}$ and $\mathrm{K}^{+}[6]$.

Nile River is one of the most known and important rivers in the world which its water outflows in the Mediterranean Sea, it is one of the world longest rivers and is the donor of life to Egypt and represents the principle freshwater resource that meets nearly all demands for drinking water and irrigation [7]. The Nile River outflows from south to north with $6,850 \mathrm{~km}$ long and over 35 degrees of latitude, its basin covers approximately $10 \%$ of the African continent with an area of $3106 \mathrm{Km}^{2}$ and spreads over 10 countries from Uganda in the south to Egypt in the north [8]. In Egypt, at the north of Cairo at Delta Barrage, the Nile River is branched into Damietta and Rosetta branches [9].

The aim of this study is to assess the impact of Nile River outflow on water quality and bacterial diversity of marine water of the Egyptian Coast of the Mediterranean Sea in Port Fouad City, Alexandria City and Damietta branch of the Nile River.

\section{Materials and methods}

\section{Sampling sites}

Marine water samples were collected from Port Fouad City with meridians of $31^{\circ} 14^{\prime} 56^{\prime \prime}$ north and latitudes of $32^{\circ} 19^{\prime} 39^{\prime \prime}$ east located at the Egyptian coast of the Mediterranean Sea and
Alexandria City with meridians of $31^{\circ} 12^{\prime} 22^{\prime \prime}$ north and latitudes of $29^{\circ} 53^{\prime} 35^{\prime \prime}$ east located at the western Egyptian coast of the Mediterranean Sea.

While riverine water samples were collected from Damietta branch of the Nile River with meridians of $31^{\circ} 25^{\prime} 10.2^{\prime}$ ' north and latitudes of $31^{\circ} 48^{\prime} 29^{\prime \prime}$ ' east.

\section{Sampling}

Composite surface water samples from Alexandria, Port Fouad and the Nile River sites were collected during the duration of four successive seasons of autumn 2014 to summer 2015. The water samples were collected in glass sterilized jars and transferred to the laboratory in ice box at $4^{\circ} \mathrm{C}$ further analysis.

\section{Water quality analysis}

Marine and riverine collected water samples were investigated for physically, chemically and bacteriologically properties.

\section{Physical analysis}

Physical analysis involved determination of water temperatures, water turbidity and TSS. Temperatures of water samples were measured in situ by submerging a graded -10:110 glass mercury thermometer in the water to more than 5 $\mathrm{cm}$ depth, turbidity of water samples were measured using Turbidimeter (LW-TN 3024) and results were recorded as NTU units. TSS concentrations were determined using method of Degen and Nussberge [10].

\section{Chemical analysis}

Chemical analysis of water samples involved determination of water salinity values, $\mathrm{pH}$ values, chlorophyll concentrations and concentrations of some nutrient salts and trace metals including: $\mathrm{Cl}^{-}$ , $\mathrm{Na}^{+}, \mathrm{K}^{+}, \mathrm{Mg}^{+2}, \mathrm{Ca}^{+2}, \mathrm{PO}_{4}^{-3}, \mathrm{NO}_{3}^{-}, \mathrm{SO}_{4}^{-2}, \mathrm{Fe}^{+3}$, $\mathrm{Cu}^{+2}, \mathrm{Zn}^{+2}$ and $\mathrm{Mn}^{+2}$.

Water salinity was measured using Master Refractometer ATAGO. While chlorophyll-a (Chl.a) concentrations were determined by filtration of a known volume of water, addition of $\mathrm{MgCO}_{3}$, grounding the filter papers and extraction overnight in $90 \%$ acetone at $4^{\circ} \mathrm{C}$, the concentrations were measured spectrophotometrically [11] using UNICO 
spectrophotometer. $\mathrm{Cl}^{-}$concentrations were determined according to Mohr's titration method with the use of $0.1 \mathrm{M}$ of $\mathrm{AgNO}_{3}$ solution and $5 \%$ di-potassium chromate indicator. $\mathrm{Ca}^{+2}$ and $\mathrm{Mg}^{+2}$ were determined using the titrimetric method of 0.01M EDTA- disodium salt solution in presence of Eriochrome Black T (EBT) and muroxide indicators [12]. Concentrations of $\mathrm{SO}_{4}^{-2}$ were determined according to the turbidity method which involves addition of $\mathrm{BaCl}_{2}$ crystals to ensure fine and stable suspension of $\mathrm{BaSO}_{4}$ at a $\mathrm{pH}$ of about 4.8 and the degree of the turbidity was measured spectrophotometrically at $490 \mathrm{~nm}$ [13] while concentrations of $\mathrm{Na}^{+}$and $\mathrm{K}^{+}$were determined using the flame photometric method [14]. Dissolved nitrates were determined spectrophotometrically using powdered cadmium to form a highly colored azo dye which was measured spectrophotometrically at $540 \mathrm{~nm}$ [15] while dissolved phosphates were determined using Murphy and Riley's molybdenum blue (MB) method [16] and concentrations were measured spectrophotometrically at $660-880 \mathrm{~nm}$. Trace metals of $\mathrm{Fe}^{+3}, \mathrm{Cu}^{+2}, \mathrm{Mn}^{+2}$ and $\mathrm{Zn}^{+2}$ were determined using the atomic absorption method [17].

\section{Total bacterial counts}

Total bacterial counts of water samples were determined using acridine orange technique of $0.1 \% \mathrm{w} / \mathrm{v}$ concentration and epifluorescence microscopy [18] Hobbie et al., (1977). The total bacterial counts were determined according to the law of $\left(\mathrm{N}=\mathrm{S}_{1}\right.$ a $\left.\mathrm{n} / \mathrm{v} \mathrm{S}_{2}\right)$ [19] Whereas; $\mathrm{N}$ was the bacterial number, $S_{1}$ was the area of the filter in $\mu \mathrm{m}^{2}$, a was the number of cells averaged of all fields, $\mathrm{n}$ was the index of breeding water samples $\mathrm{ml}, \mathrm{v}$ was the volume of suspension that was filtered in $\mathrm{ml}, \mathrm{S}_{2}$ was the area of the microscopic field of view in $\mu \mathrm{m}^{2}$.

\section{Identification of bacterial genera}

Bacterial isolates of marine and riverine water samples were morphologically and biochemically identified at the genus level according to characteristics stated in Bergey's Manual of Systematic Bacteriology [20-23].
Statistical analysis

SPSS 16.0 was used for the correlation tests.

\section{Results and discussion}

\section{Physical results}

The temperature range of Alexandria, Port Fouad and the Nile River water samples agreed with the seasonal variation of surface water temperature of the Levantine basin ranging between $14^{\circ} \mathrm{C}-$ $30{ }^{\circ} \mathrm{C}$ [24]. Water turbidity (Fig. 1) recorded the highest values during winter season which were 12.26, 17.45 and 10.54 NTU in water samples of Alexandria, Port Fouad and the Nile River, respectively. The highest values coincided with the turbulence of the coastal water, wind and wave action during winter season [25].

TSS results (Fig. 2) showed negative correlations $(\mathrm{r}=-0.327)$ between water samples of Alexandria site and Port Fouad site whereas during autumn seasons, the highest concentrations of TSS were recorded in Port Fouad water samples and the lowest concentrations were recorded in Alexandria water samples.

The highest concentration of Chl.a might be attributed to higher concentrations of $\mathrm{PO}_{4}^{-3}$ and lower concentrations of $\mathrm{NO}_{3}^{-}$, and the same findings were reported [26] as well as the higher levels of pH [27]. Similarly, TSS results showed a negative correlation $(r=-0.327)$ between the water samples of Alexandria site and Port Fouad site.

Alexandria water samples demonstrated the highest Chlorophyll-a concentrations (Fig. 3) during the warm seasons, in contrary; Port Fouad water samples demonstrated the highest concentrations during the cold seasons which agreed with previous studies [28]. Accordingly, values of Chl.a showed strong negative correlation $(\mathrm{r}=-0.984)$ between readings of Alexandria and Port Fouad sites during the seasonal duration of autumn 2014 season to summer 2015 season. Negative correlations were recorded between results of TSS and chlorophylla in water samples of Port Fouad and the Nile River. 


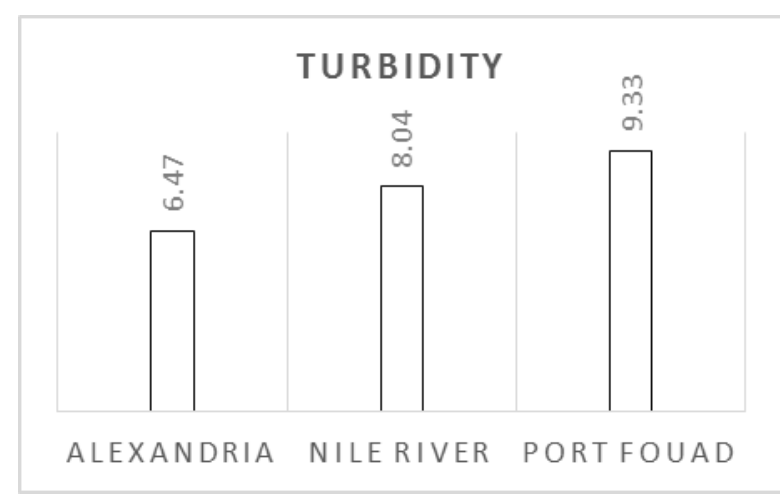

Fig. 1 Seasonal means of water turbidity in (NTU).

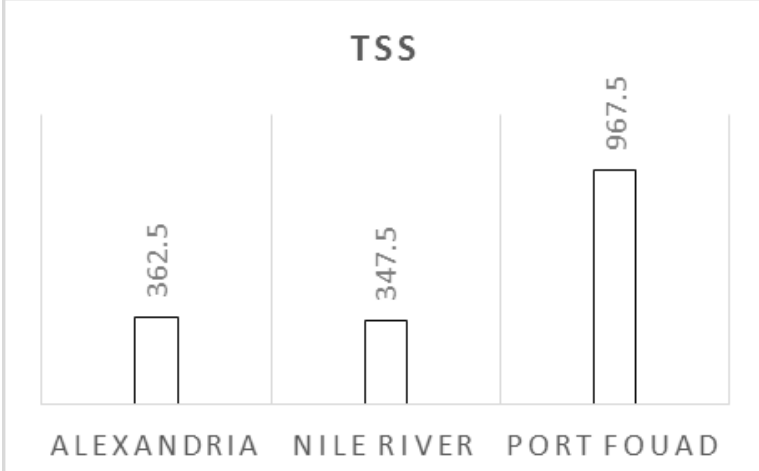

Fig. 2 Seasonal means of total suspended solids (TSS) in $\mathrm{mg} / \mathrm{l}$

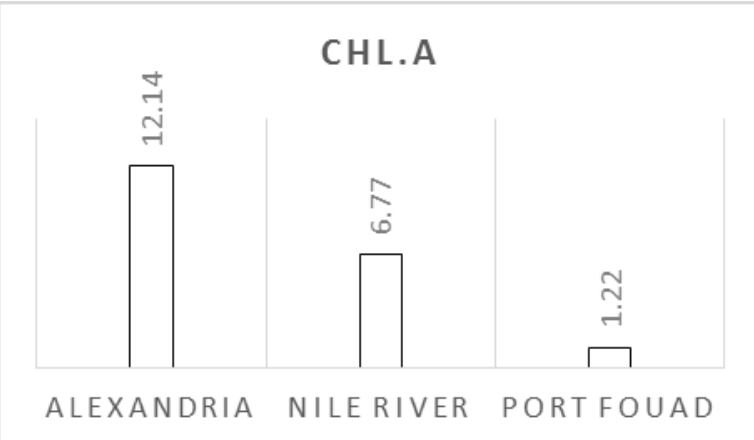

Fig. 3 Seasonal means of (Chl.a) $(\mu \mathrm{g} / \mathrm{l})$ in water samples of Alexandria, the Nile River and Port Fouad.

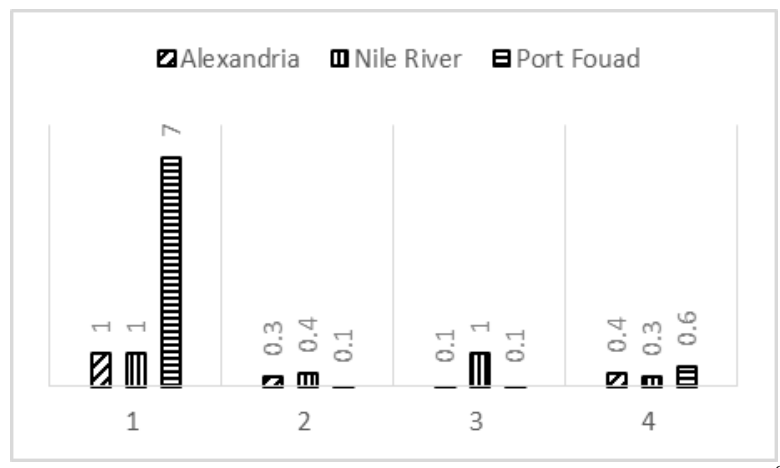

Fig. 4 Total bacterial counts of water samples in $\left(\times 10^{8}\right.$ cell $/ \mathrm{ml}$ ) of Alexandria, Port Fouad and the Nile River sites during four successive seasons (1 - 4).

\section{Chemical results}

During the four successive seasons of the study, it was noticed that water samples of Alexandria site recorded higher salinity values than those recorded in water samples of Port Fouad site which might be attributed to the outflow of riverine water of the Nile River to the eastern Mediterranean coast of Egypt [8].

The seasonal mean of water salinity of Alexandria was $46.25 \%$ while in Port Fouad water samples was $38.75 \%$. The results showed that autumn season recorded the lowest water salinity in Port Fouad water samples (table 1). The rise in salinity values in Port Fouad water samples during the three successive seasons of winter, spring and summer might be attributed to the circulation of the Suez Canal which is time dependent [29] whereas during winter to early summer water current flows from the Red Sea to the Mediterranean Sea [29]. Water salinity values of Alexandria water samples showed sharp increase during summer 2015 season than previous three seasons of the present study which was attributed to the low rainfall and high temperature and evaporation [30].

Water salinity values of the Nile River were the lowest amongst other sites where it was $17 \%$ during autumn, winter and spring seasons while it was raised to $20 \%$ during summer 2015 season.

Port Fouad site demonstrated the highest concentrations of $\mathrm{PO}^{-3}$ which was $0.825 \mathrm{mg} / \mathrm{l}$ during winter season while Alexandria site recorded the highest concentrations of $\mathrm{NO}_{3}{ }^{-}$ which was $14.7 \mathrm{mg} / \mathrm{l}$ during summer season as indicated in (table 1). Nile River water samples recorded relatively closer concentrations of $\mathrm{PO}^{-3}$ to those recorded in Port Fouad water samples and higher concentrations of $\mathrm{NO}_{3}{ }^{-}$. The high concentrations of $\mathrm{NO}_{3}{ }^{-}$might be attributed to the oxidation of ammonia to nitrite and subsequently to nitrate during summer 2015 season [31] in water samples of Alexandria and Port Fouad while the low concentrations which were recorded during spring season were attributed to the uptake of nutrients by the phytoplankton [32]. The observed variation in the concentrations of $\mathrm{PO}^{-3}$ in water samples of Port Fouad and Alexandria sites might be attributed to its concentrations in the freshwater that mixes with the seawater [31]. Therefore, concentrations of $\mathrm{PO}_{4}^{-3}$ in water samples of Port Fouad and the Nile River sites were more closely related than those between Port Fouad and Alexandria sites. The lowest concentrations of $\mathrm{PO}_{4}^{-3}$ in the water 
samples of Port Fouad and Alexandria sites during the warm seasons might be attributed to the uptake of nutrients by the phytoplankton [32]. $\mathrm{pH}$ values remained at the alkaline range of $(7.53$ -8.59 ) during the four successive seasons of the present study and relatively close means in water samples of Alexandria, Port Fouad and the Nile River were recorded as 7.89, 8.11 and 7.95 respectively.

On the other hand, concentrations of $\mathrm{Fe}^{+3}, \mathrm{~K}^{+}$, $\mathrm{SO}_{4}^{-2}, \mathrm{Na}^{+}, \mathrm{Zn}^{+2}$ and $\mathrm{NO}_{3}{ }^{-}$showed strong positive significant correlations between water samples of Alexandria site and Port Fouad site. Therefore, water samples of Port Fouad and Alexandria sites recorded higher and similar concentrations of $\mathrm{Cl}^{-}$, $\mathrm{Na}^{+}, \mathrm{K}^{+}$and $\mathrm{SO}_{4}^{-2}$ than those recorded in water samples of the Nile River. Concentrations of these nutrient salts in marine water samples of both Port Fouad and Alexandria sites agreed with those concentrations mentioned in previous studies of seawater and the eastern Mediterranean Sea [33].

The lowest concentrations of $\mathrm{K}^{+}$ion in the water samples of Alexandria, Port Fouad and the Nile River during the warm seasons might be attributed to the consumption of $\mathrm{K}^{+}$by the phytoplankton, indicating the important role of $\mathrm{K}^{+}$ion as an important limiting fertilizer for the growth of phytoplankton organisms in natural water systems at concentrations above $0.7 \mu \mathrm{mol} / \mathrm{l}$ [34].

$\mathrm{Cl}^{-}$demonstrated the highest concentrations amongst other nutrient salts with seasonal means of $22048 \mathrm{mg} / \mathrm{l}, 21545 \mathrm{mg} / \mathrm{l}$ and $12266 \mathrm{mg} / \mathrm{l}$ respectively in water samples of Alexandria, Port Fouad and the Nile River. The highest concentrations were recorded during summer season in water samples of Alexandria and the Nile River which were $28809 \mathrm{mg} / \mathrm{l}$ and 17904 $\mathrm{mg} / \mathrm{l}$ respectively, while in case of Port Fouad, it was during spring season and it was $24534 \mathrm{mg} / \mathrm{l}$. $\mathrm{Mg}^{+2}$ demonstrated the second highest concentrations after $\mathrm{Cl}^{-}$whereas the seasonal means of Alexandria, Port Fouad and the Nile River were $915.35 \mathrm{mg} / \mathrm{l}, 1131.1 \mathrm{mg} / \mathrm{l}$ and 660.75 $\mathrm{mg} / \mathrm{l}$ respectively.

Calcium is considered as the most changeable major cation in marine environment since a noticeable portion of its content is used off by marine organisms especially during spring blooming period [6]. Therefore, much lower concentrations than $\mathrm{Mg}^{+2}$ were recorded in water samples of Alexandria, Port Fouad and the Nile River sites with seasonal means of $273.45 \mathrm{mg} / \mathrm{l}$, $268.5 \mathrm{mg} / \mathrm{l}$ and $227.1 \mathrm{mg} / \mathrm{l}$ respectively.
The highest concentrations of $\mathrm{SO}^{-2}$ were mostly recorded during winter and spring seasons while autumn and summer seasons recorded relatively lower concentrations in water samples of Alexandria, Port Fouad and the Nile River sites whereas the seasonal means were $157.125 \mathrm{mg} / \mathrm{l}$, $125.25 \mathrm{mg} / \mathrm{l}$ and $25.125 \mathrm{mg} / \mathrm{l}$ respectively. Winter and spring seasons recorded the highest concentrations of $\mathrm{Na}^{+}$for Port Fouad and Alexandria sites while in case of the Nile River it was the autumn season. $\mathrm{Na}^{+}$concentrations were much higher than $\mathrm{K}^{+}$concentrations in all the water samples during the four successive seasons of the present study. The lowest concentrations of $\mathrm{Na}^{+}$were during the autumn season while in case of the Nile River it was summer 2015 season. The seasonal means of $\mathrm{Na}^{+}$concentrations in water samples of Alexandria, Port Fouad and the Nile River sites were $438.6 \mathrm{mg} / \mathrm{l}, 380.2 \mathrm{mg} / \mathrm{l}$ and $187.9 \mathrm{mg} / \mathrm{l}$ respectively.

Trace metals play important roles in the ocean, therefore iron recorded the highest concentrations over the other trace metals in the autumn season and the lowest concentrations were recorded during the spring season while the highest concentrations of copper were recorded during winter season, except for Port Fouad when the highest concentrations were recorded during the autumn season, and the lowest concentrations were recorded during summer season. Spring season recorded the highest concentrations of $\mathrm{Zn}^{+2}$ for both Alexandria and Port Fouad sites while in case of Nile River, the highest concentrations were recorded during winter season. $\mathrm{Mn}^{+2}$ mostly showed a higher concentrations than $\mathrm{Cu}^{+2}$ and $\mathrm{Zn}^{+2}$ and the highest concentrations were recorded during summer season except for Alexandria site where the highest concentration was recorded during the spring season.

The seasonal means of $\mathrm{Fe}^{+3}, \mathrm{Cu}^{+2}, \mathrm{Zn}^{+2}$ and $\mathrm{Mn}^{+2}$ ions in Alexandria were $0.655 \mathrm{ppm}, 0.025 \mathrm{ppm}$, $0.3075 \mathrm{ppm}$ and $0.407 \mathrm{ppm}$ respectively. The seasonal iron concentrations ranged between 0 ppm during winter 2015 season to $2.4 \mathrm{ppm}$ recorded during autumn season while the seasonal copper concentrations ranged between 0 ppm during autumn, spring and summer 2015 seasons to $0.1 \mathrm{ppm}$ during winter season. Seasonal $\mathrm{Zn}^{+2}$ concentrations ranged between 0 ppm during autumn season to $0.6 \mathrm{ppm}$ during spring season while the seasonal $\mathrm{Mn}^{+2}$ concentrations ranged between $0.12 \mathrm{ppm}$ during autumn season to $0.9 \mathrm{ppm}$ during spring season. 
The seasonal mean of $\mathrm{Fe}^{+3}, \mathrm{Cu}^{+2}, \mathrm{Zn}^{+2}$ and $\mathrm{Mn}^{+2}$ at Port Fouad site were $0.6 \mathrm{ppm}, 0.08 \mathrm{ppm}, 0.247$ ppm and $0.227 \mathrm{ppm}$ respectively, while the seasonal concentrations of $\mathrm{Fe}^{+3}$ ranged between $0.0 \mathrm{ppm}$ during spring season to $0.3 \mathrm{ppm}$ during winter and summer 2015 seasons. The seasonal $\mathrm{Cu}^{+2}$ concentrations ranged between $0.0 \mathrm{ppm}$ recorded during spring season to $0.2 \mathrm{ppm}$ during autumn season while in case of $\mathrm{Zn}^{+2}$, the seasonal concentrations ranged between $0 \mathrm{ppm}$ during autumn season to $0.8 \mathrm{ppm}$ during spring season. $\mathrm{Mn}^{+2}$ concentrations ranged between $0.11 \mathrm{ppm}$ during autumn to $0.36 \mathrm{ppm}$ during summer 2015 season.

The seasonal means of $\mathrm{Fe}^{+3}, \mathrm{Cu}^{+2}, \mathrm{Zn}^{+2}$ and $\mathrm{Mn}^{+2}$ in the Nile River were $0.502 \mathrm{ppm}, 0.247 \mathrm{ppm}$, $0.118 \mathrm{ppm}$ and $0.435 \mathrm{ppm}$ respectively. The seasonal $\mathrm{Fe}^{+3}$ concentrations ranged between 0.05 ppm during spring season to $1.2 \mathrm{ppm}$ during autumn season and the seasonal $\mathrm{Cu}^{+2}$ concentrations ranged between $0.11 \mathrm{ppm}$ during summer 2015 season to $0.4 \mathrm{ppm}$ during winter season. The seasonal $\mathrm{Zn}^{+2}$ concentrations ranged between $0.01 \mathrm{ppm}$ during autumn season to 0.2

Table 1. Results of the seasonal chemical parameters of salinity $(\%), \mathrm{pH}$, nutrient salts $(\mathrm{mg} / \mathrm{l})$ and trace metals (ppm) in water samples of Alexandria, the Nile River and Port Fouad.

\begin{tabular}{|c|c|c|c|c|c|c|c|c|c|c|c|c|}
\hline Site & \multicolumn{4}{|c|}{ Alexandria } & \multicolumn{4}{|c|}{ The Nile River } & \multicolumn{4}{|c|}{ Port Fouad } \\
\hline $\begin{array}{c}\text { I } \\
\text { parame } \\
\text { ter }\end{array}$ & Autumn & winter & spring & Summer & Autumn & winter & spring & Summer & Autumn & winter & spring & Summer \\
\hline $\begin{array}{c}\text { Salinity } \\
(\%)\end{array}$ & 45 & 45 & 45 & 50 & 17 & 17 & 17 & 20 & 35 & 40 & 40 & 40 \\
\hline $\mathrm{pH}$ & 8.05 & 7.53 & 8.26 & 7.72 & 8.45 & 8.15 & 7.7 & 8.01 & 8.43 & 8.59 & 8.05 & 8.03 \\
\hline $\begin{array}{c}\mathrm{Cl}^{-} \\
(\mathrm{mg} / \mathrm{l})\end{array}$ & 18613 & 23044 & 17726 & 28809 & 15422 & 7091 & 8650 & 17904 & 19144 & 22330 & 24534 & 20210 \\
\hline $\begin{array}{c}\mathrm{Na}^{+} \\
(\mathrm{mg} / \mathrm{l})\end{array}$ & 297 & 639.2 & 479.4 & 338.4 & 236.9 & 161 & 226 & 128 & 7.5 & 573.4 & 545.2 & 394.8 \\
\hline $\begin{array}{c}\mathrm{K}^{+} \\
(\mathrm{mg} / \mathrm{l})\end{array}$ & 9.4 & 10.7 & 5.9 & 7.4 & 6.4 & 4.3 & 4.7 & 3.3 & 14.3 & 15.1 & 9.2 & 9.9 \\
\hline $\begin{array}{c}\mathrm{Mg}^{+2} \\
(\mathrm{mg} / \mathrm{l})\end{array}$ & 996 & 832.4 & 1320 & 513 & 800 & 510 & 450 & 883 & 1142 & 1689 & 702.4 & 991 \\
\hline $\begin{array}{c}\mathrm{Ca}^{+2} \\
(\mathrm{mg} / \mathrm{l})\end{array}$ & 380 & 330 & 226.8 & 157 & 260 & 241 & 138 & 292.5 & 380 & 280.5 & 144.3 & 269.5 \\
\hline $\begin{array}{l}\mathrm{SO}_{4}^{-2} \\
(\mathrm{mg} / \mathrm{l})\end{array}$ & 12.8 & 335.6 & 260.3 & 19.8 & 5.6 & 2.4 & 70.8 & 21.7 & 15.2 & 332.9 & 148.7 & 4.2 \\
\hline $\begin{array}{l}\mathrm{PO}_{4}^{-3} \\
(\mathrm{mg} / \mathrm{l})\end{array}$ & 0.185 & 0.165 & 0.22 & 0.1 & 0.263 & 0.43 & 0.7 & 0.1 & 0.621 & 0.825 & 0.4 & 0.6 \\
\hline $\begin{array}{c}\mathrm{NO}_{3}^{-} \\
(\mathrm{mg} / \mathrm{l})\end{array}$ & 4.78 & 5.24 & 2.04 & 14.7 & 6 & 6.4 & 4.8 & 4.08 & 3.54 & 3.6 & 0.8 & 4.9 \\
\hline $\begin{array}{c}\mathrm{Fe}^{+3} \\
(\mathrm{ppm})\end{array}$ & 2.4 & 0.0 & 0.1 & 0.12 & 1.2 & 0.6 & 0.05 & 0.16 & 1.8 & 0.3 & 0.0 & 0.3 \\
\hline $\begin{array}{c}\mathrm{Cu}^{+2} \\
(\mathrm{ppm})\end{array}$ & 0.0 & 0.1 & 0.0 & 0.0 & 0.2 & 0.4 & 0.28 & 0.11 & 0.2 & 0.1 & 0.0 & 0.02 \\
\hline $\begin{array}{c}\mathrm{Zn}^{+2} \\
(\mathrm{ppm})\end{array}$ & 0.0 & 0.4 & 0.6 & 0.23 & 0.01 & 0.2 & 0.12 & 0.14 & 0.0 & 0.1 & 0.8 & 0.09 \\
\hline $\begin{array}{l}\mathrm{Mn}^{+2} \\
(\mathrm{ppm})\end{array}$ & 0.12 & 0.18 & 0.9 & 0.43 & 0.12 & 0.15 & 0.2 & 1.27 & 0.11 & 0.24 & 0.2 & 0.36 \\
\hline
\end{tabular}

ppm during winter season while the seasonal $\mathrm{Mn}^{+2}$ concentrations ranged between $0.12 \mathrm{ppm}$ during autumn season to $1.27 \mathrm{ppm}$ as the highest concentration amongst other sites during summer 2015 season.

Statistical results showed that concentrations of $\mathrm{Fe}^{+3}, \mathrm{Mn}^{+2}$ and $\mathrm{Ca}^{+2}$ showed strong positive significant correlations while on the other hand, the variations between marine and riverine water samples of Port Fouad and the Nile River sites were observed in results of Chlorophyll-a and TSS as well as concentrations of $\mathrm{Na}^{+}, \mathrm{Cl}^{-}, \mathrm{Mg}^{+2}$, $\mathrm{PO}_{4}^{-3}, \mathrm{NO}_{3}^{-}$which showed negative nonsignificant correlations; the results of salinity and concentrations of $\mathrm{K}^{+}$and $\mathrm{Zn}^{+2}$ showed weak nonsignificant correlations while $\mathrm{Cu}^{+2}$ showed no correlations at all. These remarkable variations in the concentrations of nutrient salts of Port Fouad and the Nile River water samples agreed to the variations mentioned in previous studies of seawater and riverine water [33] which are naturally found to occur between seawater and riverine water. 


\section{Total bacterial counts}

Examination of total bacterial counts under epifluorescent microscopy was used. According to Fig. 4, autumn season demonstrated the highest total bacterial counts of water samples of Alexandria, Port Fouad and the Nile River sites whereas the highest total bacterial counts were recorded in Port Fouad water which were $7 \times 10^{8}$ cell/ml while Alexandria and the Nile River recorded the same total bacterial counts of $1 \times 10^{8}$ cell $/ \mathrm{ml}$. Spring season demonstrated the lowest total bacterial counts in water samples of Alexandria and Port Fouad sites which recorded the same total bacterial counts as well which were $0.1 \times 10^{8} \mathrm{cell} / \mathrm{ml}$. The seasonal means of total bacterial counts in water samples of Alexandria, Port Fouad and the Nile River sites were $0.4 \times 10^{8}$ cell $/ \mathrm{ml}, \quad 2 \times 10^{8} \mathrm{cell} / \mathrm{ml}$ and $0.7 \times 10^{8} \mathrm{cell} / \mathrm{ml}$ respectively.

Unexpectedly, total bacterial counts of both marine and riverine water samples of Alexandria, Port Fouad and the Nile River sites showed the same strong positive significant correlations $(p=$ $0.00, r=0.99$ ) during the four successive seasons of the present study.

\section{Identifications of bacterial genera}

17 bacterial genera were identified morphologically and biochemically during the seasonal duration of autumn 2014 to summer 2015 whereas the identified bacterial genera varied being Gram positive and Gram negative, bacilli and cocci in shape, spore forming and non-spore forming as indicated in (table 2). They varied during the different seasons of the study whereas certain bacterial genera were isolated from all the water samples during the four successive seasons of the present study especially Vibrio sp. and Escherichia sp. while other genera were isolated occasionally during the four successive seasons.

Bacillus sp., Corynebacterium sp. and Halobacillus sp. were isolated from Port Fouad and the Nile River water samples during the same seasons as well as Vibrio sp. and Escherichia sp.

Cellulomonas sp. which is known for the degradation of cellulose was isolated on CMC agar media plates whereas positive results were observed by the formation of clear zones after 10 minutes of flooding the CMC media plates with Gram's iodine. Escherichia sp. was tested for lactose fermentation by isolation of pure bacterial cultures on MacConky agar media, positive results showed growth of creamy pink colonies after the incubation period.

Table 2. Some morphological and biochemical tests of some of the isolated bacteria.

\begin{tabular}{|c|c|c|c|c|c|c|c|c|c|c|}
\hline Genera & Gram & Cat. & Oxd. & Glu. & Man. & Stac. & Arg. & Pig. & Mot. & Spr. \\
\hline Escherichia sp. & -ve & $+\mathrm{ve}$ & $-\mathrm{ve}$ & +ve bub & +ve bub & $-\mathrm{ve}$ & -ve & W & $+\mathrm{ve}$ & $-\mathrm{ve}$ \\
\hline Vibrio $\mathrm{sp}$. & -ve & $+\mathrm{ve}$ & $+\mathrm{ve}$ & +ve bub & +ve bub & $+\mathrm{ve}$ & -ve & $\mathrm{W}$ & $+\mathrm{ve}$ & -ve \\
\hline Aerococcus sp. & $+\mathrm{ve}$ & -ve & -ve & +ve & +ve & -ve & -ve & $\mathrm{W}$ & -ve & -ve \\
\hline Lactococcus sp. & $+\mathrm{ve}$ & -ve & -ve & $+\mathrm{ve}$ & $+\mathrm{ve}$ & $+\mathrm{ve}$ & $+\mathrm{ve}$ & $\mathrm{W}$ & -ve & -ve \\
\hline Micrococcus sp. & $+\mathrm{ve}$ & $+\mathrm{ve}$ & $+\mathrm{ve}$ & $+\mathrm{ve}$ & $+\mathrm{ve}$ & var & var & $\mathrm{O}$ & -ve & -ve \\
\hline Planococcus sp. & $+\mathrm{ve}$ & $+\mathrm{ve}$ & $+\mathrm{ve}$ & -ve & $+\mathrm{ve}$ & -ve & -ve & $\mathrm{Y}$ & -ve & -ve \\
\hline Staphylococcus sp. & $+\mathrm{ve}$ & $+\mathrm{ve}$ & -ve & $+\mathrm{ve}$ & $+\mathrm{ve}$ & $+\mathrm{ve}$ & $+\mathrm{ve}$ & $\mathrm{W}$ & -ve & -ve \\
\hline Sporosarcina sp. & $+\mathrm{ve}$ & $+\mathrm{ve}$ & $+\mathrm{ve}$ & -ve & -ve & -ve & -ve & $\mathrm{W}$ & $+\mathrm{ve}$ & $+\mathrm{ve}$ \\
\hline Bacillus sp. & $+\mathrm{ve}$ & $+\mathrm{ve}$ & $+\mathrm{ve}$ & $+\mathrm{ve}$ & -ve & var & -ve & $\mathrm{W}, \mathrm{Y}$ & var & $+\mathrm{ve}$ \\
\hline Cellulomonas sp. & $+\mathrm{ve}$ & $+\mathrm{ve}$ & $+\mathrm{ve}$ & +ve bub & $+\mathrm{ve}$ & $+\mathrm{ve}$ & -ve & $\mathrm{W}$ & var & -ve \\
\hline Corynebacterium $\mathrm{sp}$ & $+\mathrm{ve}$ & $+\mathrm{ve}$ & -ve & $+\mathrm{ve}$ & $+\mathrm{ve}$ & var & -ve & $\mathrm{W}$ & -ve & -ve \\
\hline Halobacillus sp. & $+\mathrm{ve}$ & $+\mathrm{ve}$ & $+\mathrm{ve}$ & $+\mathrm{ve}$ & $+\mathrm{ve}$ & $+\mathrm{ve}$ & $+\mathrm{ve}$ & $\mathrm{Y}, \mathrm{W}$ & var & $+\mathrm{ve}$ \\
\hline Kurthia sp. & $+\mathrm{ve}$ & $+\mathrm{ve}$ & -ve & -ve & -ve & -ve & -ve & $\mathrm{W}, \mathrm{O}$ & -ve & -ve \\
\hline Lactobacillus sp. & $+\mathrm{ve}$ & -ve & -ve & $+\mathrm{ve}$ & $-\mathrm{ve}$ & -ve & -ve & $\mathrm{O}$ & -ve & -ve \\
\hline Listeria $\mathrm{sp}$. & $+\mathrm{ve}$ & $+\mathrm{ve}$ & -ve & $+\mathrm{ve}$ & $+\mathrm{ve}$ & -ve & $+\mathrm{ve}$ & $\mathrm{W}$ & $+\mathrm{ve}$ & -ve \\
\hline Microbacterium sp. & $+\mathrm{ve}$ & $+\mathrm{ve}$ & $+\mathrm{ve}$ & $+\mathrm{ve}$ & $+\mathrm{ve}$ & var & -ve & $\mathrm{Y}, \mathrm{O}$ & $+\mathrm{ve}$ & -ve \\
\hline Oceanobacillus sp. & $+\mathrm{ve}$ & $+\mathrm{ve}$ & $+\mathrm{ve}$ & +ve Oxi & -ve & -ve & -ve & $\mathrm{W}$ & $+\mathrm{ve}$ & $+\mathrm{ve}$ \\
\hline
\end{tabular}

Gram = Gram stain, Cat. = Catalase test, Oxd. = Oxidase test, Glu. = Glucose test, Man. = Mannitol test, Stac. $=$ Starch hydrolysis test, Arg. = Arginine Hydrolysis test, Pig. = Pigmentation of bacterial colony, Mot. = Motility test, Spr. = Spore Formation, var. = variable results depending on the different species of the genus, bub = production of gas bubbles, $\mathrm{Oxi}=$ oxidation, $\mathrm{Y}=$ yellow, $\mathrm{W}=$ white and $\mathrm{O}=$ orange. 


\section{Conclusion}

In conclusion, this study proved that there was an impact of the flowing Nile River water on the eastern Mediterranean Sea coast of Egypt according to the significant variations that were observed between the marine water samples which were collected from Alexandria city and Port Fouad city especially between the concentrations of certain nutrient salts including: $\mathrm{Mg}^{+2}, \mathrm{Ca}^{+2}, \mathrm{PO}_{4}^{-3}$ and $\mathrm{NO}_{3}^{-}$as well as salinity values which were usually much higher in the water samples of Alexandria site than Port Fouad site. This variation between marine water samples has no logical reason except for the impact of the Nile River water on Port Fouad water which lowered the water salinity at this site.

The impact of the flowing Nile River water into the eastern Mediterranean Sea was confirmed by the significantly related results of water turbidity, $\mathrm{pH}$ levels and the relatively close concentration of $\mathrm{NO}_{3}{ }^{-}, \mathrm{HCO}_{3}{ }^{-}$and trace metals during the seasonal duration of autumn 2014 to summer 2015 in the water samples of Port Fouad and the Nile River sites when compared to those results of Alexandria site.

The variations in nutrient salt concentrations of $\mathrm{Mg}^{+2}, \mathrm{Ca}^{+2}, \mathrm{Na}^{+}$and $\mathrm{K}^{+}$between Port Fouad and the Nile River water samples were documented in previous studies of marine water and riverine water as well as the variations in bacterial genera.

\section{References}

[1] E. M. Ali, A. S. Sami, S. I. Abdel Rahman, A. S. El Shenawy, Characterization of Chemical Water Quality in the Nile River, Egypt, Int. J. Pure App. Biosci. 2 (3) (2014) 35-53.

[2] M. Coll, C. Piroddi, J. Steenbeek, K. Kaschner, F. B. R. Lasram, J. Aguzzi, E. Ballesteros, C. N. Bianchi, J. Corbera, T. Dailianis, R. Danovaro, M. Estrada, C. Froglia, B. S. Galil, J. M. Gasol, R. Gertwagen, J. Gil, F. Guihaumon, K. KesnerReyes, M.-S. Kitsos, A. Koukouras, N. Lampadariou, E. Laxamana, C. M. López-Fé de la Cuadra Lotze, H. K. D, D. Martin, D. Mouillot, S. Oro, J. Raiceyvich, J. I. Rius-Barile, C. SaizSalinas, S. Somot, J. Templado, X. Turon, D. Vafidis, R. Villaneuva, E. Voultsiadou, The biodiversity of the Mediterranean Sea: Estimates, patterns, and threats. PloS. One. 5 (2010) 11842.

[3] E. Bosc, A. Bricaud, D. Antoine, Seasonal and interannual variability in algal biomass and primary production in the Mediterranean Sea, as derived from 4 years of Sea WiFS observations. Global Biogeochem Cycles. 18 (2004) 1005.

[4] I. Siokou-Frangou, U. Christaki, M. G. Mazzocchi, M. Montresor, D. A. Ribera, Plankton in the open Mediterranean Sea: a review. Biogeosci Disc. 7 (2010) 1543-1586.

[5] R. B. Nessim, H. R.Z. Tadros, A. E. A. Abou Taleb, M. N. Moawad, Chemistry of the Egyptian Mediterranean coastal Waters. Egyptian J. Aquatic Research. 41 (2015) 1-10.

[6] M. Revel, E. Ducassou, F. Grousset, E. S. M. Bernasconi, S. Migeon, S. Revillon, J. Mascle, A. Murat, S. Zaragosi, D. Bosch, 100000 years of African monsoon variability recorded in sediments of the Nile margin. Quaternary Sci. Rev. 29 (2010) 1342-1362.

[7] S. M. Ali, S. Z. Sabae, M. Fayez, N. A Hegazi, Sugar and starch industries as a potential source of water pollution of the Nile River south of Cairo: Microbiological and chemical studies. Egyptian J. Academic Society for Environmental development. 9 (2008) 25-45.

[8] D. R. Karyabwite, Water sharing in the Nile River valley. Project GNV011: Using GIS/Remote sensing for the sustainable use of natural resources. UNEP/DEWA/GRID. Geneva. (2000).

[9] A. A. Elewa, M. B. Shehata, L. F. Mohamed, M. H. Badr, G. S. Abdel-Aziz, Water quality characteristics of the Nile River at Delta Barrage with reference to Rosetta branch. Global J. of Environmental Research. 3(1) (2009) 1- 6.

[10] J. Degen, F. E. Nussberger Notes on the determination of suspended solids. Sewage Ind. Wastes. 28 (1956) 237.

[11] H. Rai, "Methods Involving the Determination of Photosynthetic Pigments using Spectrophotometry", Verh, Internat. Verein. Limnol. 18 (1973) 1864-1875.

[12] J. Devis, Freitas, Calcium plus Magnesium, Physical and Chemical Methods of Soil and Water Analysis, Food and Agriculture Organization of the United Nations, Rome, Italy, Soil Bulletin. 10 (1970) 212-215.

[13] D. Singh, P. K. Chhonkar, R.N. Pande, Assessment of Irrigation Water Quality in "Soil, Plant, Water Analysis" - A methods manual, Indian Agricultural Research Institute. Indian Council of Agricultural Research, New Delhi. 3 (1999a) 107-109.

[14] D. Singh, P. K. Chhonkar, R.N. Pande, Assessment of Irrigation Water Quality in "Soil, Plant, Water Analysis" - A methods manual, Indian Agricultural Research Institute. Indian Council of Agricultural Research, New Delhi. 3 (1999b) 76-78. 
[15] H. P. Hansen, F. Koroleff, K. Grasshoff, K. Kremling, E. M. Hrhardt, Methods of seawater analysis. Wiley-VCH, Weinheim, Germany. (1999) P 15-228.

[16] J. Murphy, J. P. Riley, A modified single solution method for the determination of phosphate in natural waters. Anal. Chim. Acta. 27 (1962). 31-6.

[17] J. Ramiraz-Munoz, Atomic Absorption Spectroscopy and Analysis by Atomic Absorption Flame Photometry. American Elsevier Publishing Co. New York, N.Y. (1968) pp 920.

[18] J. E. Hobbie, R. J. Daley, S. Jasper, Use of Nuclepore filters for counting bacteria by fluorescence microscopy. Appl Environ Microbiol. 33 (1977) 1225-1228.

[19] L. M. Polyanskaya, R. B. Gorodnichev, D. G. Zvyagintsev, Published in Izvestiya Akademii Nauk, Seriya Biologicheskaya. 2 (2013) 144-151.

[20] D. J. Brenner, N. R. Krieg, J. T. Staley, G. M. Garrity, Bergy's Manual of Systematic Bacteriology, 2 ${ }^{\text {nd }}$ edn. (2) 2005.

[21] P. D. Vos, G. M. Garrity, D. Jones, N. R. Krieg, W. Ludwig, F. A. Rainey, K. H. Schleifer, W. B. Whitman, Bergy's Manual of Systematic Bacteriology, $2^{\text {nd }}$ edn. (3) 2009.

[22] N. R. Krieg, J. T. Staley, D. R. Brown, B. P. Hedlund, B. J. Paster, N. L. Ward,W. Ludwig, W. B. Whitman, Bergy's Manual of Systematic Bacteriology, $2^{\text {nd }}$ edn. (4) 2010.

[23] M. Goodfellow, P. Kämpfer, H. J. Busse, M. E. Trujillo, K. I. Suzuki, W. Ludwig, W. B. Whitman, Bergy's Manual of Systematic Bacteriology, 2 ${ }^{\text {nd }}$ edn. (5) 2012.

[24] B. S. Galil, A. Zenetos,"A sea change-exotics in the Eastern Mediterranean Sea." Invasive Aquatic Species of Europe. Distribution, Impacts and Management. Springer Netherlands, (2002) P. 325-336.

[25] S. W. Nixon, Physical energy inputs and the comparative ecology of lake and marine ecosystems. Limnol. Oceanogr. 33 (1988) 1005 1025 .
[26] H. M. Khairy, N. R. Hussein, H. M. Faragallah, M. M. Dorgham, The phytoplankton communities in two eutrophic areas on the Alexandria coast, Egypt. Revista de Biología Marina y Oceanografía. 49 (2) (2014) 267-277.

[27] A. I. Lopez-Archilla, D. Moreira, P. LopezGarcia, C. Guerrero, Phytoplankton diversity and cyanobacterial dominance in a hypereutrophic shallow lake with biologically produced alkaline pH. Extremophiles. 8 (2004) 109-115.

[28] F. F. Madkour, The potential impact of Lake Manzala on the phytoplankton and hydrographic characters of the Suez Canal, Egypt. Egypt. J. Aquat. Biol. And Fish.11 (2) (2007) 185- 204.

[29] J. Baussan, Variations annuelles de niveau le long du canal de Suez. Revue de Geographie physique et de Geologie Dynamique. 9 (1983) 293 - 321.

[30] S. Kamallkanth, M. Muniyan, Christyponni A. Seasonal variations in physico-chemical parameters at Tranquebar Coastal Nagapattinam, Tamilnadu. India. Int. J. Environ. Biol. 2 (2012) 203-207.

[31] S. V. Rai, M. Rajashekhar, Seasonal assessment of hydrographic variables and phytoplankton community in the Arabian Sea waters of Kerala, southern coast of India. Brazilian J. oceanography. 62(4) (2014) 279-293.

[32] S. Z. Sabae, A. M. Abdel-Satar, Chemical and bacteriological studies on El-Salam Canal, Egypt. J. Egypt. Acad. Soc. Environ. Develop. 2(1) (2001) $173-197$.

[33] G. R. Bigg, The oceans and climate 2nd Ed. Cambridge: Cambridge University Press. (2003)

[34] J. F. Talling, Potassium- a non-limiting nutrient in fresh waters. Fresh Water Reviews 3 (2010) 97104. 
الملخص العزبي

عنوان البحث: تأثير تدفق نهر النيل على جودة المياه والتتوع البكتيري للمياه البحرية لساحل البحر الأبيض المتوسط فى مصر لتأير تلفق

نوران أشرف زرمبة1*، مجدي محسن بهجت2 ، محمد إسماعيل أبو دباره33، محمود محمد زكى1 1

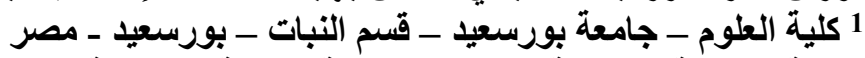

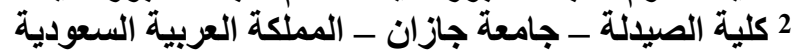

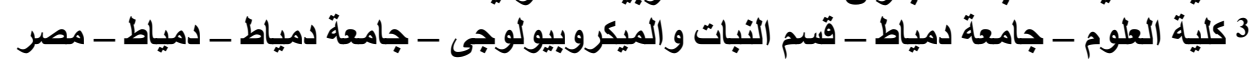

تمت المقارنة بين السواحل الثرقية والغربية للبحر الأبيض المتوسط في مصر عن طريق تجميع عينات

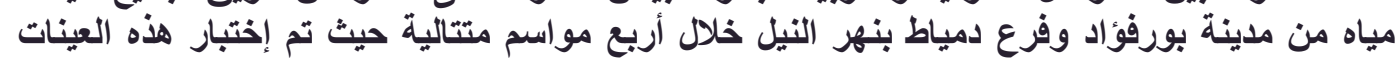

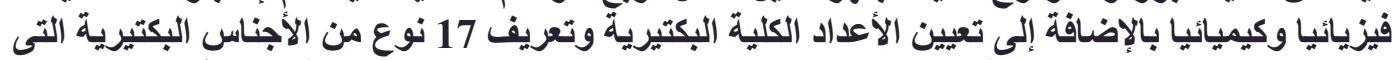

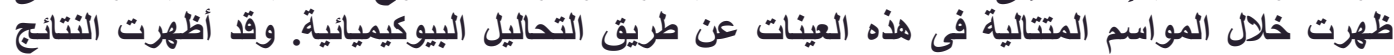

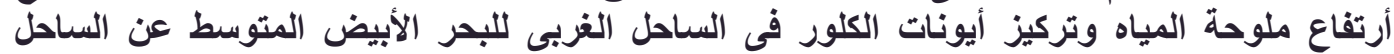

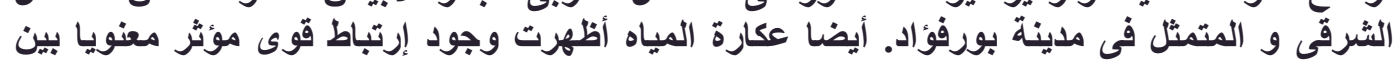

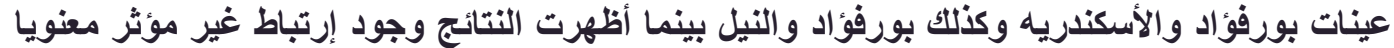
بين عينات الأسكندرية ونهز النيل. 